\title{
Surging glaciers in Greenland - a status
}

\author{
Anker Weidick
}

New wide-angle vertical aerial photography covering most of West and East Greenland were flown in the years 1981 and 1985 by Mark Hurd Corp., Minneapolis, Minnesota, for the Geodetic Institute, Copenhagen. The photographs are on a scale of approximately $1: 150000$, so that single photographs cover a large area, and are valuable as bench marks for glacier changes. These photographs have been used for updating information on West Greenland glacier changes and the history of West Greenland glacier surges. Those covering East Greenland have been used for location of important centres of surging glaciers.

\section{Procedure}

Glacier surges are defined as a mass "transfer of a large volume of ice from a reservoir area to a receiving area" (Paterson, 1981, p. 279). Usually surges are located by diagnostic features resulting from the surging activity, such as strong crevassing, complex lobation of the frontal areas, or widespread pitting of the glacier surface. Since these features 'heal' with time a full coverage of glacier surges in a given region requires repeated aerial photography over several decades. This has been possible in West Greenland where the glacier surges concentrated around Disko island and Nûgssuaq peninsula are well documented.

In East Greenland new photographic coverage in 1981 has pinpointed areas around the Blosseville Kyst as having the highest frequency of glacier surges in Greenland. The possibility of unravelling the surge history is more restricted here and has not yet been attempted; the present article indicates some of the trends.

\section{Disko and Nâgssuaq}

Both areas were among the first to be mapped by the Geodetic Institute (map sheets 1:250 000 in 1931/33), and since 1942 they have been covered by aerial photography on several occasions. About a score of glaciers exhibit more or less pronounced morphological criteria of glacier surges, but at only half of them can surge events be documented and dated.

Individual localities. On the basis of the documented surges and delay in healing of surge features, reces- sional rates of the glacier fronts during quiescent phases, and geomorphological ice-contact features of the foreland, an approximate age of older surge events can be suggested for some of the glaciers (fig. 1). Nearly all the surging glaciers are located in areas of Tertiary basalt overlying and intercalated by Cretaceous sediments. Only a single glacier (1IB26003-Agssakait sermia) is situated in the area of Archaean gneiss.

In fig. 1 the position of the glacier fronts are generally shown as the distance from the neoglacial outer moraines. Exceptions are 1HD06030-Stordal and 1HB15012-Kuanerssuit where the reference points are at a supposed minimum of glacier advance in the last 100-200 years but where maximum extension of the neoglacial advances might be essentially greater. The frontal advances are shown with arrows. Hatched arrows indicate documented and dated advances, and plain arrows those suggested from the evidence described above. The extent of the advances is indicated by the position of the arrow point.

The frontal recession in the quiescent phase is at rates of $10-100 \mathrm{~m}$ per year, but thinning of the glacier is usually more pronounced. This implies that the outer glacier lobe of some of the glaciers can become detached over thresholds and then transformed into dead ice. During the surges, the reactivated glacier lobes in some cases move over old glacier ice, and in one example (1HE09051-Kûganguaq head) the advancing glacier front does not extend beyond the margin of the ice of the former glacier, so that two contemporaneous, recessional curves have to be drawn.

General trends of the surges. Information on the eleven surging glaciers is mainly restricted to the most recent surge events, but even here the evidence for the events of the glaciers on Agatfjeldet (1HE09090 and 1HE09095) is questionable. For three glaciers (1HB10013, 1HD06030 and 1IA02034) two events, and for one glacier (1HB10036, cf. fig. 2) three events can be suggested. The quiescent phase for all the examples given seems to be around thirty to fifty years while the surge event lasts for up to a few years.

The magnitude of the frontal variations due to the surges vary between one and a little more than two kilometres. A general feature is that the surges in the last century did not reach the neoglacial maximum and that there is a tendency for subsequent surge advances 


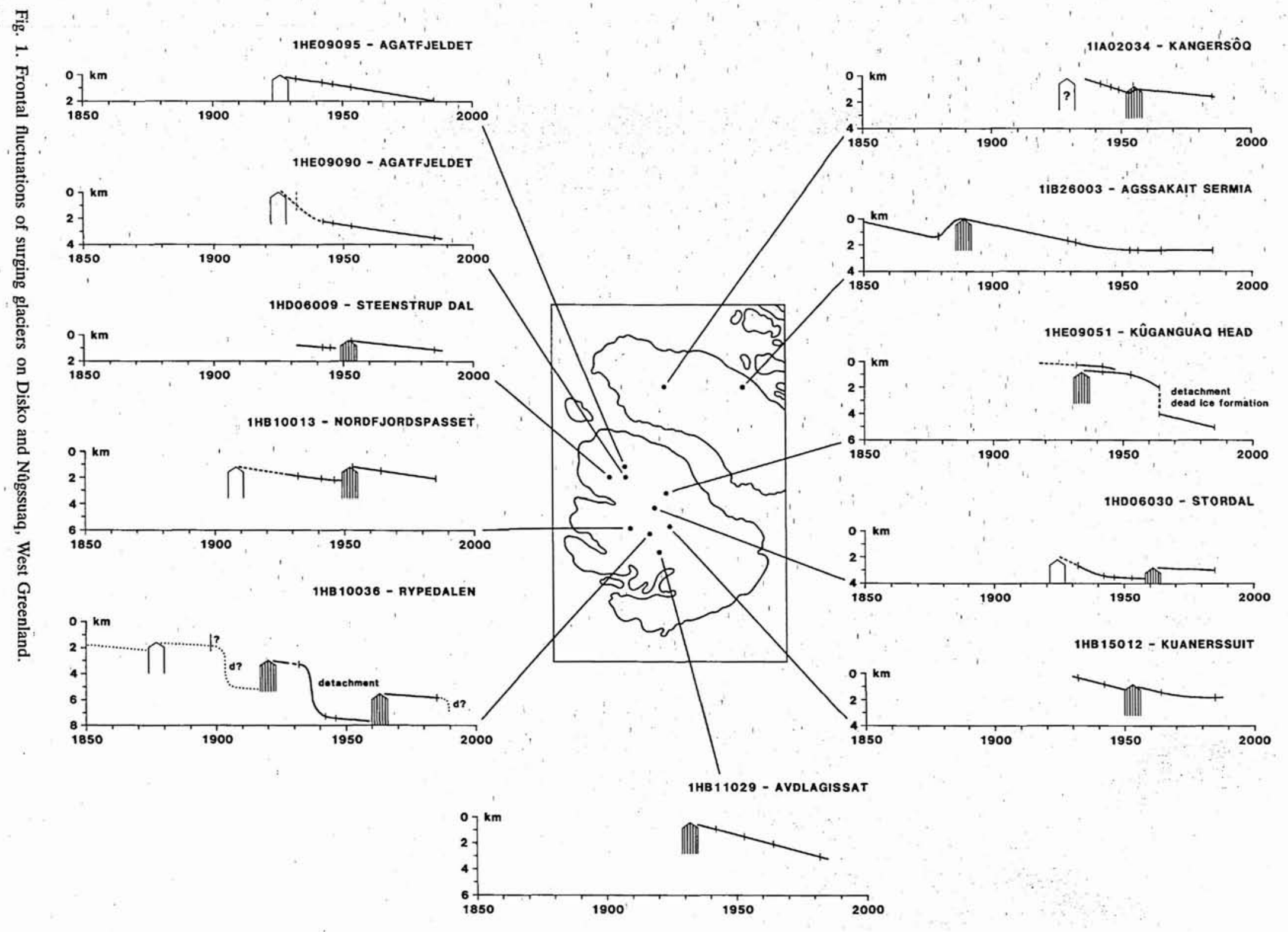




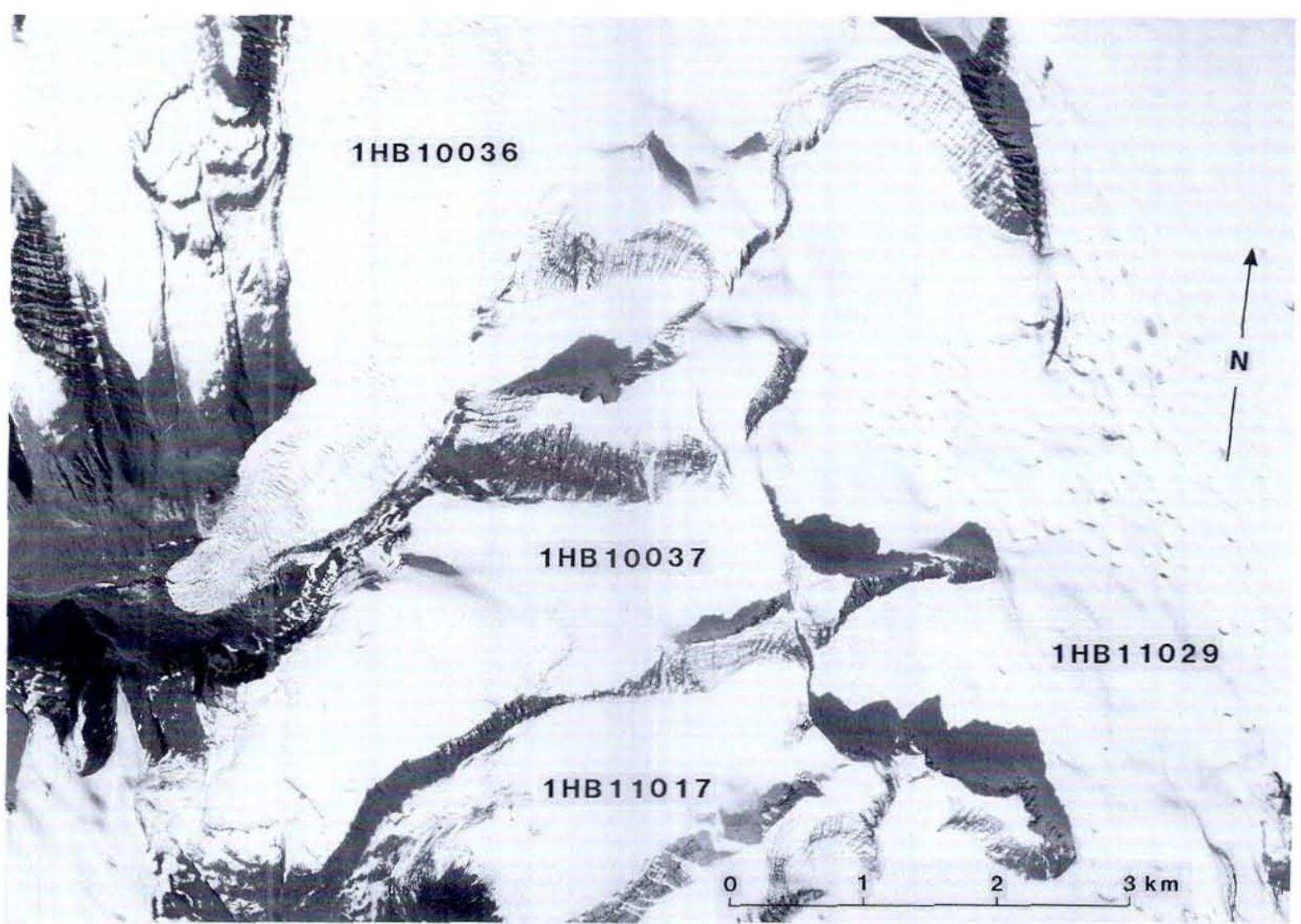

Fig. 2. Strongly crevassed surface of a surging glacier (glacier 1HB10036) and a pitted surface of a glacier witnessing a former surge (glacier 1HB11029), central Disko. Aerial photograph Geodetic Institute route 268E no. 268 of August 27 th, 1964. Reproduced with permission A. 200/87.

to be smaller. This must be connected with the general glacier thinning of the same period which also caused decreasing surge activity: thus no evidence of recent surges in the region can be found on the latest aerial photograph coverage of the region in 1985.

Evidence which could have been interpreted as relict structures has been found on a number of glaciers other than those described. Possibly many glaciers of the region passed through a period of optimum conditions for surging during the 'Little Ice Age' and the observations presented here just indicate the end of this period for the glaciers in the region.

\section{Other parts of West Greenland}

In spite of extensive work on the registration of all West Greenland glaciers, little evidence of surging has been found outside the regions of Disko and Nûgssuaq. Surge behaviour in the middle of the 19th century may possibly have brought the outlet of an ice cap, Sermeq in Søndre Sermilik fjord in South Greenland, $12 \mathrm{~km}$ down the fjord (Weidick, 1984a), and in the same region a pulsation of an outlet of the Inland Ice (Eqalorutsit kitdlit sermiat) around 1944 suddenly caused the front to advance 3-4 km down the fjord which might be interpreted as surge-like behaviour (Weidick, 1984b).

\section{East Greenland}

The first observation of surges in East Greenland was made during GGU field work in the Scoresby Sund region, where descriptions of the glacier Løberen were given by Henriksen \& Watt (1968) and Olesen \& Reeh (1969), and of Bjørnbo Gletscher by Rutishauser (1971). Both glaciers are situated in the Stauning Alper, a mountainous area of Caledonian migmatites and granites (Henriksen \& Higgins, 1976, especially map fig. 198 , p. 218). The length of the quiescent phase has not been determined in the case of Løberen where the documented surge took place in the early 1960 s, but a preceding quiescent phase must have covered several decades or even a century of downwasting of a $7 \mathrm{~km}$ 


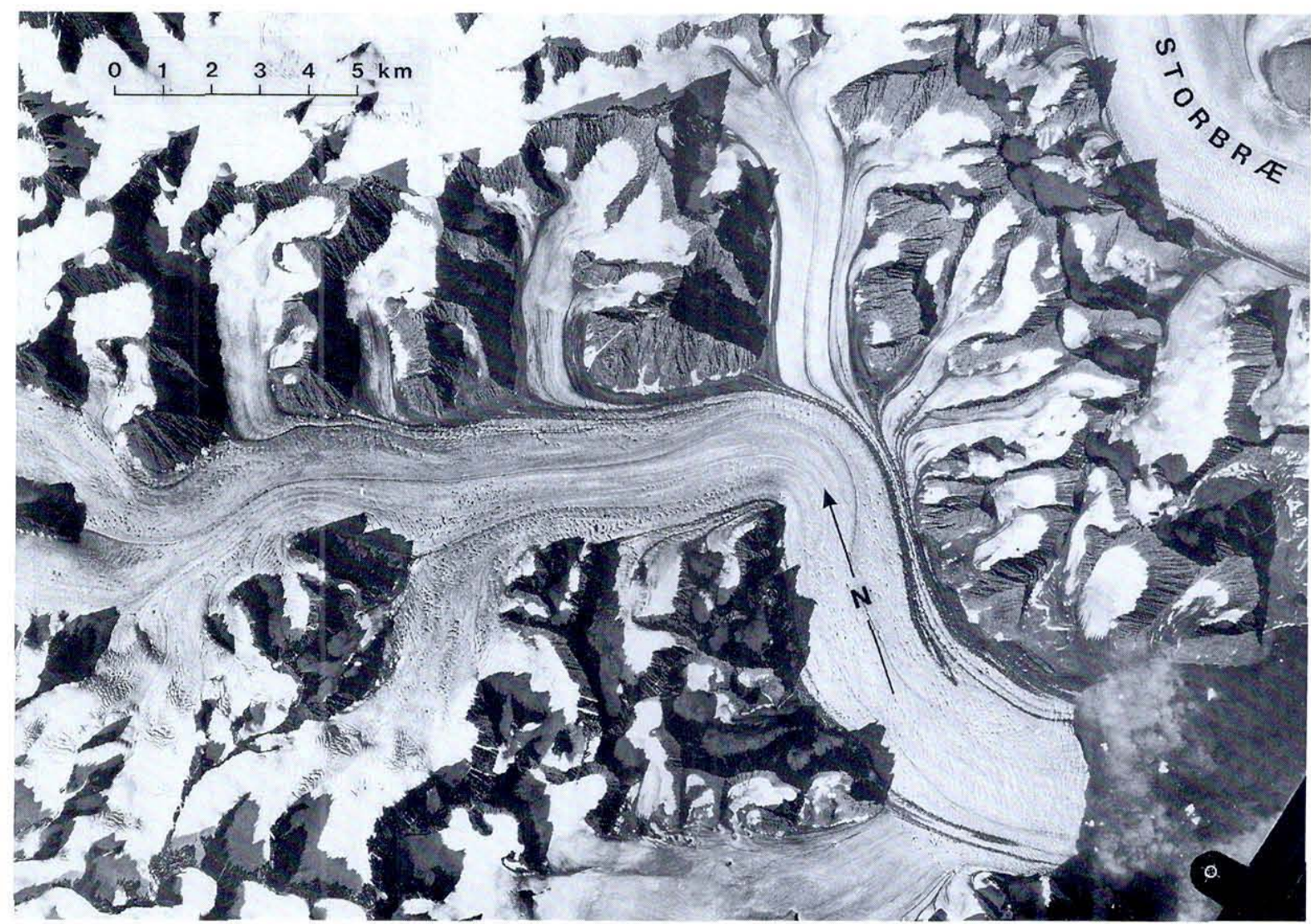

Fig. 3. Unnamed glacier at Johan Petersen Bugt, Blosseville Kyst, East Greenland (approximately $68^{\circ} 50^{\prime} \mathrm{N}, 26^{\circ} 30^{\prime} \mathrm{W}$ ). The surface is strongly pitted after a former surge. Aerial photograph, Geodetic Institute route 878 B no. 1964 of August 14th, 1981. Reproduced with permission A. 200/87.

long glacier lobe with a maximum thickness of at least $300 \mathrm{~m}$. As far as Bjørnbo Gletscher is concerned, Rutishauser $(1971$, p. 236) suggests an interval of 100 years between a surge around 1890 and an expected one at around 1990.

More surges can probably be documented in the Scoresby Sund region, since a number of glaciers indicate structures which might be interpreted as results of surges. However, the greatest concentration of active surging glaciers can be observed on aerial photographs of the stretch between Scoresby Sund and Kangerdlugssuaq. Here a study of the most recent aerial photographs from 1981 (fig. 3) gives good evidence (crevassing, pitting and lobation of moraines) of surging events at 26 localities. The coverage of older photographs of the region is probably insufficient for detailed documentation of events, and thus the glaciers plotted in fig. 4 must indicate a minimum of surges in the region. A widespread pitting of the firn area of the large unnamed glacier south of Torvgletscher in this region is described by Rucklidge (1966), but without connecting their origin to surges.

The area of Scoresby Sund - Kangerdlugssuaq is built up of Tertiary basalts as in the case of the DiskoNûgssuaq area on the west coast.

\section{Regional occurrences of surges in Greenland}

Although no systematic investigation of surging glaciers has been made in Greenland, the examples described here are evidence of widespread occurrence of this behaviour, especially in the basalt provinces of West and East Greenland. This might imply a connection of many surges to special conditions of permeability or roughness of the subsurface, as pointed out by Post (1969) for glacier surges in North America.

The surging glaciers range from modest cirque glaciers to great outlets of ice fields or ice caps, which in East Greenland form complex systems of merging ice streams. 


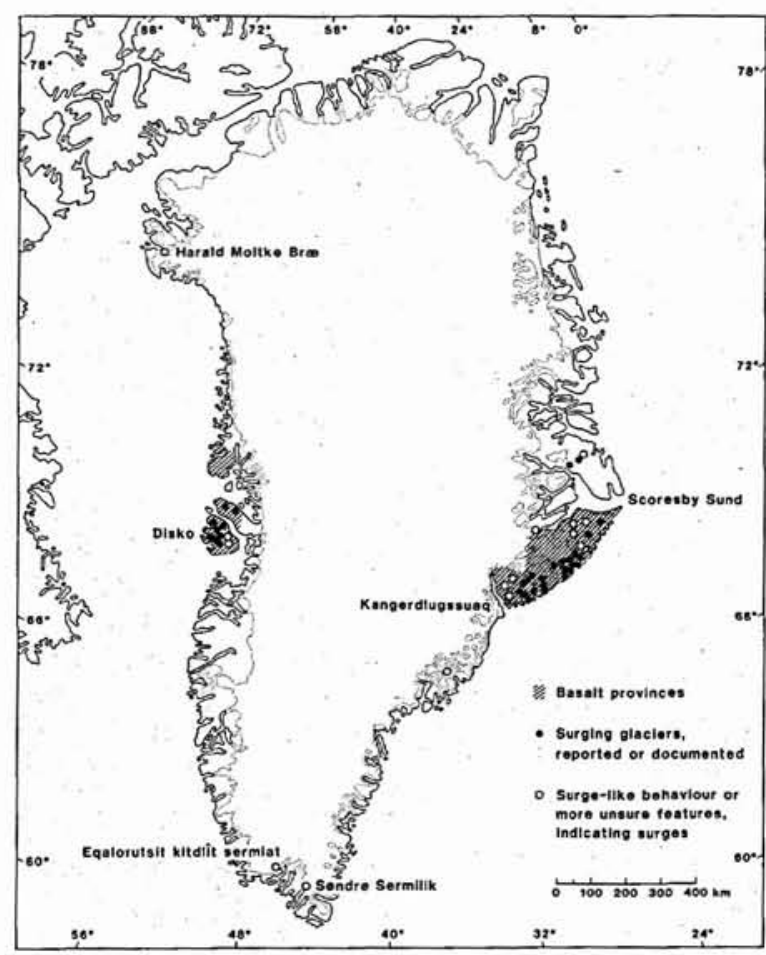

Fig. 4. Surging glaciers in Greenland.

\section{Classification of surges according to time}

Dating of events is possible for only a few of the surging glaciers. The ice covers of the wide plateaus of Disko seem very sensitive to climatic fluctuations; rise of the climatic snow line by only about $200 \mathrm{~m}$ in the last century meant that large areas of the ice bodiés here were converted from accumulation areas to ablation areas.

Apart from the general thinning of the glaciers on Disko and Nûgssuaq, it is possible to study an area where glaciers in most recent time pass from a surging phase to a 'normal one'. This is not the case for the East Greenland localities, which are essentially situated in areas where fluctuations of the climatic snow line rarely imply the same consequences as in West Greenland. Specific conditions apply to the Inland Ice margin where only a single event of pulsation of the outlet Eqalorutsit kitdlit sermiat in South Greenland has been documented (Weidick, 1984b).

The ice streams of the Inland Ice have been labelled 'permanent surges', which in a systematic sense can only be connected with the temporary surges described above in so far as there is a gradation between:

(1) Glacier areas with more or less continuous surging (ice streams).

(2) Glaciers with more or less repeated temporary surge events.

(3) Glaciers with a single surge event.

Transitions between (1) and (2) might be found in the East Greenland basalt area of complex systems of outlets from large ice caps, or possibly from the example of the calf-ice producing outlet from the Inland Ice in North-West Greenland (Harald Moltke Bræ)..The latter glacier is normally regarded as in permanent surge, but its velocity near the front has varied in this century between $30 \mathrm{~m} /$ year and $1 \mathrm{~km} /$ year or more (Mock, 1966).

Transitions between (2) and (3) can be either isolated glaciers that only pass through a period of surge conditions for a short time, or where the glacier area is so extensive that a build up for surging takes considerably longer than the 10-100 years (Paterson, 1981, p. 289) usually recorded for a quiescent phase.

\section{References}

Henriksen, N. \& Higgins, A. K. 1976: East Greenland Caledonian Fold Belt. In Escher, A. \& Watt, W. S. (edit.): Geology of Greenland, 182-246. Copenhagen: Geol. Surv. Greenland.

Henriksen, N. \& Watt, W. S. 1968: Geological reconnaissance of the Scoresby Sund Fjord complex. Rapp. Grønlands geol. Unders. 15, 72-77.

Mock, S. J. 1966: Fluctuations of the terminus of Harald Moltke Bræ, Greenland. J. Glaciol. 6, 369-373.

Olesen, O. B. \& Reeh, N. 1969: Preliminary report on glacier observations in Nordvestfjord, East Greenland. Rapp. Grønlands geol. Unders. 21, 41-53.

Paterson, W. S. B. 1981: The physics of glaciers, 2nd ed., 380 pp. Oxford: Pergamon Press.

Post, A. 1969: Distribution of surging glaciers in Western North America. J. Glaciol. 8, 229-240.

Rucklidge, J. 1966: Observations of hollows in the snow surface of Torv Gletscher, East Greenland. J. Glaciol. 6, 446449.

Rutishauser, H. 1971: Observations on a surging glacier in East Greenland. J. Glaciol. 10, 227-236.

Weidick, A. 1984a: Studies of glacier behaviour and glacier mass balance in Greenland - a review. Geogr. Annlr 66A, 183-195.

Weidick, A. 1984b: Location of two glacier surges in West Greenland. Rapp. Grønlands geol. Unders. 120, 100-104. 